\title{
PENGARUH TINGKAT PENDAPATAN, PENDIDIKAN DAN PEKERJA TERHADAP LITERASI KEUANGAN IBU RUMAH TANGGA DI KECAMATAN JETIS
}

\author{
Melati Rellyasari \\ Universitas Sarjanawiyata Tamansiswa \\ e-mail : mrellyasari@gmail.com
}

\begin{abstract}
This study aims to examine whether the level of income affects the financial literacy of housewives, whether the level of education affects the financial literacy of housewifes and whether the level of work affects the financial literacy of housewifes. In this study taking samples of working and non-working housewifes in Kecamatan Jetis Yogyakarta. The method used in this research is data collection conducted by distributing questionnaires to working and non-working housewifes with a total 80 respondents. The result showed that every working and non-working housewifes had expertise in managing or allocating their finances from the perspective of income, education and employment.Surveys prove that income, education and employment affect financial literacy.
\end{abstract}

\begin{abstract}
ABSTRAK
Penelitian ini bertujuan untuk menguji apakah tingkat pendapatan berpengaruh terhadap literasi keuangan ibu rumah tangga, apakah tingkat pendidikan berpengaruh terhadap literasi keuangan ibu rumah tangga dan apakah tingkat pekerjaan berpengaruh terhadap literasi keuangan ibu rumah tangga. Dalam penelitian ini mengambil sampel ibu rumah tangga yang bekerja dan tidak bekerja di Kecamatan Jetis Yogyakarta. Metode yang digunakan dalam penelitian ini adalah pengumpulan data yang dilakukan dengan menyebarkan kuesioner kepada ibu rumah tangga yang bekerja dan tidak bekerja dengan jumlah 80 responden. Hasil penelitian menunjukkan bahwa setiap ibu rumah tangga yang bekerja dan tidak bekerja memiliki keahlian dalam mengelola atau mengalokasikan keuangannya dari segi pendapatan, pendidikan dan pekerjaan. Penelitian membuktikan bahwa pendapatan, pendidikan dan pekerjaan mempengaruhi literasi keuangan.
\end{abstract}

Kata Kunci : Pendapatan, Pendidikan, Pekerjaan dan Literasi Keuangan Ibu Rumah Tangga

\section{PENDAHULUAN}

Pengelolaan keuangan dalam kehidupan sehari-hari tidak akan terlepas dari literasi keuangan di dalam mengambil keputusan keuangan yang tepat (Ratna 2017). Menurut Surat Edaran Otoritas Jasa Keuangan Nomor 30/SEOJK/07/2017, Literasi Keuangan adalah pengetahuan, keterampilan, dan keyakinan yang mempengaruhi sikap dan berperilaku untuk meningkatkan kualitas pengambilan keputusan dan pengelolaan keuangan dalam rangka mencapai kesejahteraan ( menurut Otoritas Jasa Keuangan 2017) dalam penelitian (Marpis Ade, Cholid Idham, 2017)

Hasil survei yang dilakukan Otoritas Jasa Keuangan terkait tingkat literasi keuangan ibu rumah tangga di Indonesia masih rendah, yakni sekitar 2,18\%. Jumlah ibu rumah tangga di Indonesia cukup banyak,tetapi tingkat literasi nya masih rendah ( Kepala Eksekutif 


\section{Buletin Ekonomi}

Edukasi dan Perlindungan Konsumen OJK, Kusumaningtuti S. Soetiono,di Jakarta, Kamis 7 Agustus 2014). Survei ini melibatkan 34 provinsi, survei pertama pada tahun 2013 di 20 provinsi dengan melibatkan 8.000 orang responden dan jumlah kota 40. Dari 40 kota meningkat menjadi 64 kota pada tahun 2016 dengan melibatkan 9.680 responden. Indeks literasi keuangan tertinggi di DKI Jakarta 40 persen, Jawa Barat 38,70 persen, DIY 38,55 persen dan Bali 37,45 persen. Indeks literasi keuangan terendah di Papua Barat 19,27 persen, NTB 21,45 persen, Papua 22,18 persen, Sulawesi Tengah 22,55 persen, Kalimantan Selatan dan Gorontalo 23,27 persen. (Lubis, 2017)

Berdasarkan hasil penemuan yang dilakukan bahwa tingkat literasi keuangan dapat menunjang kehidupan baik pekerjaan maupun kebutuhan sehari-hari, lalu literasi keuangan masyarakat terhadap lembaga jasa keuangan didominasi oleh industri perbankan(Dwiastanti \& Hidayat, 2016). Mengenai objek yang diteliti banyak faktor-faktor dalam literasi keuangan yang saling berpengaruh terhadap usia, tingkat pendapatan, tingkat pengeluaran, tingkat pendidikan dan pekerjaan(Ary Gantika, 2018).

Berdasarkan penelitian yang dilakukan oleh penelitian terdahulu bahwa literasi keuangan pada ibu rumah tangga sangat berpengaruh pada lingkungan yang berkaitan dengan variabel ibu yang bekerja dan tidak bekerja, pendidikan, dan pendapatan.

Lemahnya literasi keuangan ibu rumah tangga dengan keterkaitan usia, tingkat pendidikan, tingkat pekerjaan, tingkat pendapatan dan pengelolaan keuangan ibu rumah tangga. Penelitian ini mengumpulkan beberapa rumusan masalah, sebagai berikut:

1. Apakah tingkat pendidikan berpengaruh terhadap literasi keuangan ibu rumah tangga?

2. Apakah tingkat pekerjaan berpengaruh terhadap literasi keuangan ibu rumah tangga?

3. Apakah tingkat pendapatan berpengaruh terhadap literasi keuangan ibu rumah tangga?

Pendapatan dalam kamus manajemen adalah uang yang diterima oleh perorangan, perusahaan dan organisasi lain dalam bentuk gaji, sewa, upah, bunga komisi. Pendapatan seseorang juga dapat didefinisikan sebagai banyaknya penerimaan yang dinilai dengan satuan mata uang yang dapat dihasilkan seseorang dalam periode tertentu. Pendapatan adalah penerimaan gaji atau balas jasa dari hasil usaha yang diperoleh individu atau kelompok rumah tangga dalam sebulan dan digunakan untuk memenuhi kebutuhan sehari-hari(Mulyani, 2016). Sedangkan pendapatan dari usaha sampingan adalah pendapatan tambahan yang merupakan penerimaan lain dari luar aktivitas pokok atau pekerjaan pokok(Mulyani, 2016).

Financial Management Behaviour berhubungan dengan tanggung jawab keuangan seseorang mengenai cara pengelolaan keuangan mereka(Purwidianti, Wida dan Mudjiyanti, 2013). Tanggung jawab keuangan adalah proses pengelolaan keuangan dan aset lainnya dengan cara yang dianggap produktif. Hal ini juga berkaitan dengan proses penggunaan aset keuangan.

Pekerjaan merupakan suatu kegiatan yang dilakukan oleh manusia dalam mencari penghasilan atau nafkah untuk memenuhi suatu kebutuhan yang dirasa sangat penting atau dibutuhkan untuk diri sendiri atau untuk keluarga nya agar tercapai semua yang di inginkan atau target yang ingin diwujudkan. Dengan bekerja kita dapat mengelola waktu (disiplin), mengelola keuangan, mempunyai rasa tanggung jawab tinggi, dan mempunyai pengalaman dalam berkarir.

Literasi Finansial sebagai salah satu literasi dasar menawarkan seperangkat penawaran pengetahuan dan keterampilan untuk mengelola sumber daya keuangan secara efektif untuk kesejahteraan hidup sekaligus kebutuhan dasar bagi setiap orang untuk meminimalisasi, mencari solusi, dan membuat keputusan yang tepat dalam masalah keuangan. Literasi Finansial juga memberikan pengetahuan tentang pengelolaan dan pemanfaatan sumber daya sebagai amunisi untuk pembentukan dan penguatan sumber daya 


\section{Buletin Ekonomi}

manusia Indonesia yang kompeten, kompetitif dan beintegritas dalam menghadapi persaingan di era globalisasi dan pasar bebas dan juga sebagai warga negara dan warga dunia yang bertanggung jawab dalam pelestarian alam dan lingkungan dalam pemenuhan kebutuhan hidup dan kesejahteraan (Dikdasmen, 2017).

\section{METODE}

Penelitian ini adalah penelitian kuantitatif yang digunakan untuk meneliti populasi atau sampel tertentu dan pengumpulan data menggunakan instrument penelitian. Penelitian yang dilakukan ini menggunakan metode penelitian deskriptif. Penelitian deskriptif merupakan penelitian yang melakukan pengumpulan data berupa gambaran penelitian, penjelasan yang lebih detail mengenai fenomena atau objek dan pengumpulan subjek penelitian.

Dalam pengambilan data penelitian ini, peneliti menggunakan teknik pengumpulan data berupa kuesioner pada Ibu Rumah Tangga di Kecamatan Jetis Yogyakarta. Pengumpulan data ini melalui pengumpulan data pendukung dari sampel penelitian, literatur, jurnal dan buku-buku referensi untuk menggambarkan masalah yang diteliti. Data pendukung ini diperoleh dengan menggunakan kuesioner tertutup, dalam kuesioner tersebut sudah disediakan semua alternatif jawaban yang sudah mewakili variabel yang diteliti, sehingga responden hanya memilih alternatif jawaban yang sesuai dengan pilihan.

Sumber dari pengumpulan data tersebut dari sampel atau kuesioner yang sesuai dengan karakteristik Ibu Rumah Tangga di Kecamatan Jetis Yogyakarta

Populasi dalam penelitian ini adalah ibu rumah tangga yang tinggal di daerah Kecamatan Jetis Yogyakarta.

Dalam penelitian ini tidak memungkinkan semua populasi yang akan penelti teliti. Peneliti akan mengambil populasi ibu rumah tangga di daerah Kecamatan Jetis 100 orang Karena populasi merupakan semua data ibu rumah tangga yang bekerja dan tidak bekerja. Populasi Maka dari itu peneliti hanya mengambil beberapa data ibu rumah tangga yang bekerja maupun tidak bekerja berupa sampel 80 orang sehingga dapat menghemat waktu.

Sampel yang akan peneliti ambil 80 orang. Dalam penelitian ini menggunakan rumus slovin sebagai berikut

$\mathrm{n}=\frac{\mathrm{N}}{\left(1+\mathrm{N}(\mathrm{e})^{2}\right.}$

Dimana

$\mathrm{n}$ : jumlah sampel

$\mathrm{N}$ : jumlah populasi

e : batas toleransi kesalahan

\section{ANALISIS DAN PEMBAHASAN}

Penelitian ini menggunakan sampel ibu rumah tangga yang berlokasi di Daerah Kecamatan Jetis Yogyakarta. Data yang digunakan dalam penelitian ini mengggunakan kuesioner yang dilaksanakan kurang lebih seminggu. Jumlah responden dalam penelitian ini ada $80 \mathrm{ibu}$ rumah tangga. Dalam pengambilan data, peneliti melakukan pencarian responden dengan cara datang ke rumah masing-masing ibu rumah tangga dengan membagi kuesioner atau mewawancari secara langsung ibu rumah tangga yang ada di Daerah Kecamatan Jetis Yogyakarta.

Tujuan dari penelitian ini adalah untuk mengetahui apakah ada pengaruh dalam tingkat literasi keuangan ibu rumah tangga yang ditinjau dari tingkat pendapatan, tingkat pendidikan dan tingkat pekerjaan yang berada di Daerah Kecamatan Jetis, Yogyakarta Berdasarkan penelitian yang diperoleh dari penyebaran kuesioner pada ibu rumah tangga 


\section{Buletin Ekonomi}

dapat diperoleh dari tingkat pendapatan, tingkat pendidikan, tingkat pekerjaan dan tingkat literasi keuangan ibu rumah tangga.

Tabel 1. Uji Validitas

\begin{tabular}{cccc}
\hline Item & r Hitung & r Tabel & Keterangan \\
\hline Y1 & 0.611 & & \\
Y2 & 0.639 & & \\
Y3 & 0.552 & & \\
Y4 & 0.577 & & \\
Y5 & 0.296 & 0.2172 & Valid \\
Y6 & 0.468 & & \\
Y7 & 0.438 & & \\
Y8 & 0.466 & & \\
Y9 & 0.262 & & \\
Y10 & 0.268 & & \\
\hline
\end{tabular}

Berdasarkan tabel variabel literasi keuangan (Y) memiliki nilai signifikan $r$ hitung $>$ dari $r$ tabel, dimana untuk mengetahui $\mathrm{r}$ tabel $=\mathrm{n}-2$ (signifikan 5\%). Sehingga dapat disimpulkan bahwa data tersebut Valid

Tabel 2. Reliabilitas

Deskripsi Data Reliabilitas

\begin{tabular}{ll} 
Cronbach Alpha & $\mathrm{N}$ of Item \\
\hline 0.695 & 11
\end{tabular}

Dalam Uji Reliability total literasi keuangan (Y) memiliki nilai alpha sebesar $0.695>$ dari 0.6. Sehingga dapat disimpulkan bahwa reliabel karena nilai alpha Cronbach > dari 0.6

Tabel 3. Normalitas

One-Sample Kolmogorov-Smirnov Test

\begin{tabular}{llrrrr}
\hline & & Pendapatan & Pendidikan & Pekerjaan & Literasi_Keuangan \\
\hline $\mathrm{N}$ & & 80 & 80 & 80 & 80 \\
Normal & Mean & 2.15 & 2.92 & 1.62 & 26.29 \\
Parameters $^{\mathrm{a}}{ }^{2}$ & Std. & .887 & .991 & .487 & 4.246 \\
& Deviation & .280 & .280 & .404 & .094 \\
Most Extreme & Absolute & .280 & .270 & .275 & .092 \\
Differences & Positive & -.220 & -.280 & -.404 & -.094 \\
& Negative & 2.501 & 2.506 & 3.616 & .842 \\
Kolmogorov-Smirnov Z & .000 & .000 & .000 & .478 \\
Asymp. Sig. (2-tailed) & & & & \\
\hline
\end{tabular}

Berdasarkan dari tabel hasil Uji Normalitas menggunakan metode ini menunjukkan bahwa hasil signifikan sebesar 0.478 dimana hasil tersebut $0.478>$ dari signifikan 0.05 . Sehingga dapat disimpulkan bahwa Uji Normalitas pada penelitian ini terdistribusi Normal 


\section{Buletin Ekonomi}

Tabel 4. Multikolonearitas

\begin{tabular}{lccl}
\hline Model & Tolerance & VIF & Keterangan \\
\hline Pendapatan & 0.724 & 1.381 & \\
Pendidikan & 0.790 & 1.266 & Tidak Terjadi Multikolonearitas \\
Pekerjaan & 0.901 & 1.110 & \\
\hline
\end{tabular}

Pada Uji Multikolinearitas terdapat Tolerance dan VIF, dimana variabel X1 bisa dilihat bahwa Tolerance 0.724 dan VIF 1.381 lalu variabel X2 Tolerance 0.790 dan VIF 1.266. Dan variabel yang terakhir Tolerance 0.901 dan VIF 1.110. Berdasarkan tabel diatas variabel X1 memiliki nilai Tolerance sebesar $0.724>$ dari 0.10 dan nilai VIF sebesar $1.381<$ dari 10.00. Lalu variabel X2 memiliki nilai Tolerance sebesar $0.790>$ dari 0.10 dan nilai VIF sebesar $1.266<$ dari 10.00. Dan variabel X3 memiliki nilai Tolerance sebesar $0.901>$ dari 0.10 dan nilai VIF sebesar $1.110<$ dari 10.00 Maka bisa dikatakan bahwa dalam variabel X1, X2, X3 tidak terjadi gejala multikolinearitas karena nilai Tolerance $>0.10$ dan nilai VIF $<10.00$

Tabel 5. Heteroskedastisitas

\begin{tabular}{lll}
\hline Variabel & Signifikan & Keterangan \\
\hline X1 & 0.443 & \\
X2 & 0.920 & Tidak terkadi heteroskedastisitas \\
X3 & 0.204 & \\
\hline
\end{tabular}

Dalam uji ini variabel X1 memiliki nilai signifikan 0.443 , X2 memiliki nilai signifikan 0.920 dan X3 memiliki nilai 0.204 yang dimana variabel X1 nilai signifikan $0.443>$ dari 0.05 . variabel X2 nilai signifikan $0.920>$ dari 0.05 dan variabel X3 nilai signifikan $0.204>$ dari 0.05. Dari tiga variabel tersebut maka dapat disimpulkan bahwa dalam uji ini tidak terjadi heteroskedastisitas

Tabel 6. Uji t

\begin{tabular}{lcccc}
\hline Model & B & Std. Error & $\mathrm{t}$ & Sig \\
\hline Konstanta & 21.227 & 1.911 & 11.109 & 0.000 \\
Pendapatan & -0.018 & 0.284 & -0.062 & 0.951 \\
Pendidikan & 1.136 & 0.521 & 2.183 & 0.032 \\
Pekerjaan & 1.085 & 1.003 & 1.082 & 0.283 \\
\hline
\end{tabular}

Tabel 7. Uji F

\begin{tabular}{lrcccc}
\hline Model & Sum of Square & df & Mean Square & $F$ & Sig \\
\hline Regression & 133.336 & 3 & 44.445 & 2.616 & 0.057 \\
Residual & 1291.051 & 76 & 16.986 & & \\
\hline Total & 1424.388 & 79 & & & \\
\hline
\end{tabular}

\section{i. Pengujian $\mathrm{H} 1$}

Diketahui bahwa nilai t hitung pendapatan (X1) sebesar -0.410. Dimana nilai $t$ hitung $>\mathrm{t}$ tabel maka terdapat pengaruh variabel $\mathrm{X}$ terhadap $\mathrm{Y}$. Dan nilai $\mathrm{t}$ hitung $<\mathrm{t}$ table maka tidak terdapat pengaruh variabel X terhadap Y. Nilai t hitung X1 $-0.410<$ dari t tabel 1.66412 maka dapat simpulkan bahwa H1 ditolak sehingga tidak terdapat pengaruh variabel $\mathrm{X} 1$ terhadap variabel $\mathrm{Y}$

H1 = Pendapatan tidak berpengaruh terhadap Literasi Keuangan 


\section{Buletin Ekonomi}

\section{ii. Pengujian $\mathrm{H} 2$}

Diketahui bahwa nilai t hitung pendidikan (X2) sebesar 2.303. Maka nilai t hitung $2.303>$ dari t tabel 1.66412. Sehingga dapat disimpulkan H2 diterima karena t hitung $>$ dari t tabel yang artinya terdapat pengaruh variabel $\mathrm{X} 2$ terhadap variabel $\mathrm{Y}$

$\mathrm{H} 2$ = Pendidikan berpengaruh terhadap Literasi Keuangan

\section{iii. Pengujian $\mathrm{H} 3$}

Diketahui bahwa nilai t hitung pekerjaan (X3) sebesar 1.266. Dimana nilai t hitung $<$ dari t tabel maka tidak terdapat pengaruh terhadap Y. Pada variabel X3 nilai t hitung sebesar $1.266<$ dari t tabel 1.66412. Sehingga dapat disimpulkan bahwa H3 ditolak karena variabel X3 tidak terdapat pengaruh terhadap variabel Y.

H3 = Pekerjaan tidak berpengaruh terhadap Literasi Keuangan

iv. Pengujian $\mathrm{H} 4$

Berdasarkan tabel yang ada diatas pengujian secara simultan $\mathrm{X} 1, \mathrm{X} 2$, dan $\mathrm{X} 3$ terhadap Y memiliki nilai $F$ hitung sebesar 2.616. Sehingga $F$ hitung $2.616>$ dari 2.49 maka dapat disimpulkan bahwa $\mathrm{H} 4$ diterima yang artinya semua variabel independen secara simultan berpengaruh terhadap variabel dependen .

H4 = secara simultan Pendapatan, Pendidikan dan Pekerjaan berpengaruh terhadap Literasi Keuangan

Hipotesis

1. Pengaruh Tingkat Pendapatan Terhadap Literasi Keuangan Ibu Rumah Tangga Di Daerah Kecamatan Jetis

Pendapatan

Pendapatan dalam kamus manajemen adalah uang yang diterima oleh perorangan, perusahaan dan organisasi lain dalam bentuk gaji, sewa, upah, bunga komisi. Pendapatan seseorang juga dapat didefinisikan sebagai banyaknya penerimaan yang dinilai dengan satuan mata uang yang dapat dihasilkan seseorang dalam periode tertentu. Pendapatan adalah penerimaan gaji atau balas jasa dari hasil usaha yang diperoleh individu atau kelompok rumah tangga dalam sebulan dan digunakan untuk memenuhi kebutuhan sehari-hari(Mulyani, 2016). Sedangkan pendapatan dari usaha sampingan adalah pendapatan tambahan yang merupakan penerimaan lain dari luar aktivitas pokok atau pekerjaan pokok(Mulyani, 2016).

Pendapatan yang diperoleh umumnya dari usaha sendiri, atau bekerja dengan orang lain. Dan untuk ibu rumah tangga yang tidak bekerja pada umumnya pendapatan diperoleh dari pendapatan suami. Pendapatan juga bisa digabungkan antara pendapatan suami dan isteri.

Pada uji multikolonearitas variabel pendapatan (X1) memiliki nilai Tolerance sebesar $0.738>$ dari 0.10 lalu nilai VIF sebesar $1.354<$ dari 10.00 . Uji multikolonearitas ini untuk memastikan adanya hubungan antara pendapatan terhadap literasi keuangan ibu rumah tangga. Di lihat dari hasil tersebut bahwa tidak terdapat gejala multikolonearitas atau bebas dan pada variabel pendapatan (X1) memiliki nilai signifikan $0.997>$ dari 0.05 maka tidak terjadi gejala heteroskedastisitas. Lalu pada uji hipotesis diatas bahwa bisa di lihat dari hasil penelitian yang menunjukkan variabel X1 memiliki nila $t$ hitung $<\mathrm{t}$ tabel yaitu $\mathrm{t}$ hitung $-0.410<\mathrm{t}$ tabel 1.66412 . Sehingga dapat disimpulkan dari semua data bahwa tingkat pendapatan beerpengaruh terhadap literasi keuangan ibu rumah tangga. 


\section{Buletin Ekonomi}

2. Tingkat Pendidikan Berpengaruh Terhadap Literasi Keuangan Ibu Rumah Tangga Di Daerah Kecamatan Jetis

Pendidikan

Pendidikan dalam literasi keuangan merupakan suatu proses pembelajaran berupa pengetahuan dan keterampilan dalam mengelola keuangan dengan bijak. Pendidikan merupakan proses dimana kita diminta atau di didik untuk memiliki pemahaman terrhadap apapun dan menjadi orang yang kritis dalam berpikir. Pendidikan memiliki jenjang tingkat, semakin tinggi pendidikan yang kita raih maka kita memiliki pengetahuan ilmu yang bermanfaat dan memiliki keterampilan yang luas.

Dari hasil tabel diatas uji multikolonearitas, variabel pendidikan (X2) memiliki nilai Tolerance $0.825>$ dari 0.10 dan nilai VIF sebesar 1.212 < dari 10.00 artinya ada hubungan antara pendidikan terhadap literasi keuangan ibu rumah tangga. Di lihat dari hasilnya bahwa nilai Tolerance $>0.10$ dan VIF < dari 10.00 tidak terjadi gejala multikolonearitas lalu variabel X2 memiliki nilai Asym.Sig $0.329>$ dari 0.05 maka tidak terjadi gejala heteroskedastisitas. Lalu pada uji hipotesis pendidikan (X2) memiliki nilai t hitung $2.303>$ dari $t$ tabel 1.66412. Dikatakan bahwa nilai t hitung > dari $\mathrm{t}$ tabel maka diterima. Dari hasil penelitian uji hipotesis tersebut variabel pendidikan (X2) diterima karena data tersebut > dari t tabel. Sehingga dapat disimpulkan dari semua data bahwa tingkat pendidikan berpengaruh terhadap literasi keuangan ibu rumah tangga

3. Pengaruh Tingkat Pekerjaan Terhadap Literasi Keuangan Ibu Rumah Tangga Di Daerah Kecamatan Jetis

Pekerjaan

Pekerjaan ialah sekumpulan kedudukan (posisi) yang memiliki persamaan kewajiban atau tugas-tugas pokoknya. Dalam kegiatan analisis jabatan, satu pekerjaan dapat diduduki oleh satu orang, atau beberapa orang yang tersebar di berbagai tempat. Dalam arti luas Pekerjaan adalah aktivitas utama yang dilakukan oleh manusia. Dalam arti sempit, istilah pekerjaan digunakan untuk suatu tugas atau kerja yang menghasilkan uang bagi seseorang. (Budi Santoso, 2012)

Pada uji multikolonearitas variabel pekerjaan (X3) memiliki nilai Tolerance 0.884 > dari 0.10 dan nilai VIF sebesar $1.131<$ dari 10.00. Bisa dikatakan bahwa tidak terjadi multikolonearitas karena nilai Tolerance > dari 0.10 dan nilai VIF < dari 10.00. Maka dari hasil tersebut terdapat hubungan antara pekerjaan terhadap literasi keuangan ibu rumah tangga. Variabel pekerjaan (X3) memiliki nilai signifikansi $0.648>$ dari 0.05 maka tidak terjadi gejala heteroskedastisitas

Lalu dalam uji hipotesis variabel pekerjaan (X3) memiliki nilai t hitung $1.266<\mathrm{t}$ tabel 1.66412. Dari hasil penelitian tersebut bahwa variabel pekerjaan (X3) ditolak karena nilai $t$ hitung < dari t tabel. Sehingga dapat disimpulkan dari semua data yang diperoleh bahwa tingkat pekerjaan berpengaruh terhadap literasi keuangan Dikarenakan hasil dari penelitian uji hipotesis yang menghasilkan nilai yang kurang atau tidak memenuhi syarat maka disimpulikan bahwa tingkat pekerjaan berpengaruh negative terhadap literasi keungan ibu rumah tangga

4. Pengaruh Tingkat Pendapatan, Pendidikan, Pekerjaan Secara Simultan Terhadap Literasi Keuangan Ibu Rumah Tangga Di Daerah Kecamatan Jetis

Secara simultan pendapatan, pendidikan, dan pekerjaan saling berpengaruh atau berhubungan. Pendapatan adalah penghasilan dari suatu kegiatan yang menghasilkan usaha berupa kerja keras sehingga dapat memenuhi kebutuhan sehari - hari. Pendidikan adalah suatu ilmu pengetahuan dalam memanajemen dan mengelola literasi keuangan sehingga literasi keuangan seimbang. Lalu pekerjaan adalah 


\section{Buletin Ekonomi}

kegiatan yang harus dilakukan (usaha atau kerja keras) sehingga bisa menghasilkan sesuatu yang bermanfaat. Sehingga disimpulkan bahwa secara simultan saling berkaitan, yang dimana pendapatan jika ingin mempunyai atau mengahasilkan suatu pendapatan maka harus usaha atau memiliki suatu pekerjaan. Pekerjaan, jika ingin memiliki tingkat pekerjaan atau jabatan maka harus memiliki pendidikan atau pengetahuan yang luas.

5. Tingkat Literasi Keuangan Ibu Rumah Tangga Di Daerah Kecamatan Jetis Literasi keuangan

Literasi Finansial sebagai salah satu literasi dasar menawarkan seperangkat penawaran pengetahuan dan keterampilan untuk mengelola sumber daya keuangan secara efektif untuk kesejahteraan hidup sekaligus kebutuhan dasar bagi setiap orang untuk meminimalisasi, mencari solusi, dan membuat keputusan yang tepat dalam masalah keuangan. Literasi Finansial juga memberikan pengetahuan tentang pengelolaan dan pemanfaatan sumber daya sebagai amunisi untuk pembentukan dan penguatan sumber daya manusia Indonesia yang kompeten, kompetitif dan beintegritas dalam menghadapi persaingan di era globalisasi dan pasar bebas dan juga sebagai warga negara dan warga dunia yang bertanggung jawab dalam pelestarian alam dan lingkungan dalam pemenuhan kebutuhan hidup dan kesejahteraan (Dikdasmen, 2017)

Berdasarkan pada tabel diatas variabel terikat (Y) literasi keuangan memiliki nilai Alpha 0.695 > dari signifikan 0.6 maka variabel literasi keuangan dikatakan reliabel. Keseluruhan variabel independent dan dependent memiliki nilai Asymp.Sig $0.478>$ dari signifikansi 0.05 maka terdistribusi normal.

Lalu pada uji t hipotesis variabel terikat (Y) berpengaruh positif terhadap variabel bebas $\mathrm{X} 2$, sedangkan untuk variabel $\mathrm{X} 1$ dan $\mathrm{X} 3$ berpengaruh negative terhadap variabel terikat. Berbeda pada uji $\mathrm{f}$ hipotesis berdasarkan pengujian simultan variabel independent $\mathrm{X} 1, \mathrm{X} 2, \mathrm{X} 3$ terhadap variabel dependent $\mathrm{Y}$ memiliki nilai signifikan yang artinya bahwa saling berpengaruh, jadi variabel dependent $(Y)$ berpengaruh atau terdapat hubungan antara variabel independent X1, X2 dan X3.

Dalam regresi alinear berganda variabel terikat (Y) literasi keuangan memiliki pengaruh terhadap variabel bebas X1, X2 dan X3 sehingga dapat disimpulkan bahwa variabel pendapatan, pendidikan dan pekerjaan mempunyai pengaruh atau hubungan terhadap variabel terikat (Y).

\section{KESIMPULAN DAN SARAN}

Adanya pengaruh tingkat pendapatan terhadap literasi keuangan ibu rumah tangga di kecamatan jetis nilai (Asymp.Sig 0.683 < nilai Alpha Cronbach 0.05). Dilihat dari hasil bahwa ibu rumah tangga di kecamatan jetis memiliki tingkat pendapatan rendah dibawah UMK, memiliki tingkat pendapatan sedang dan tinggi tetapi 30\% ibu rumah tangga memiliki tingkat pendapatan rendah dibawah UMK. Dari hasil penelitian tersebut lebih baik tingkat pendapatan rendah daripada tingkat literasi yang rendah. Meskipun ibu rumah tangga yang berpenghasilan rendah tetap pandai atau mampu untuk memanajemen keuangan nya.

Adanya pengaruh tingkat pendidikan terhadap literasi keuangan ibu rumah tangga di kecamatan jetis (nilai Asymp.Sig 0.024 > dari nilai Alpha Cronbach 0.05). Di lihat dari hasil penelitian bahwa ibu rumah tangga di kecamatan jetis memiliki tingkat pendidikan yang tinggi, terdapat $56.2 \%$ ibu rumah tangga di kecamatan jetis lulus SMA. Semakin tinggi tingkat pendidikan kita akan memiliki tingkat literasi yang tingga. Jika rendah nya tingkat pendidikan maka kita memiliki tingkat literasi yang rendah. Meskipun ibu rumah tangga di 


\section{Buletin Ekonomi}

kecamatan jetis rata - rata tidak sampai ke jenjang pendidikan yang tinggi, mereka tetap ikut berpartisipasi atau mengikuti kegiatan yang diadakan di lingkungan tentang pengetahuan umum literasi keuangan.

Adanya pengaruh tingkat pekerjaan terhadap literasi keuangan ibu rumah tangga di kecamatan jetis ( nilai Asymp.Sig $0.209>$ nilai Alpha Cronbach 0.05). Di lihat dari hasil penelitian bahwa ibu rumah tangga di kecamatan jetis yang bekerja terdapat $62.5 \%$ sedangkan ibu rumah tangga yang tidak bekerja terdapat $37.5 \%$. Pekerjaan berpengaruh terhadap literasi keuangan karena rata - rata ibu rumah tangga yang bekerja memiliki ruang lingkup yang luas dan pengalaman yang banyak sehingga banyak ibu rumah tangga yang memilih untuk bekerja di samping itu mendapatkan penghasilan yang bisa dipakai untuk kebutuhan sendiri dan keluarga. Ibu rumah tangga yang tidak bekerja memiliki ruang lingkup yang kecil dan kemungkinan mempunyai wawasan yang kurang sehingga tidak dapat berkembang kecuali memiliki inisiatif untuk berkarya dalam rumah seperti berwirausaha.

Literasi keuangan ibu rumah tangga di kecamatan jetis ( nilai Alpha Cronbach $0.695>$ nilai signifikan 0.6). Di lihat dari hasil penelitian diatas bahwa keseluruhan variabel bebas atau independent $\mathrm{X} 1, \mathrm{X} 2, \mathrm{X} 3$ dan variabel terikat atau dependent $\mathrm{Y}$ secara simultan memiliki nilai signifikansi dan terdapat hubungan antara variabel independent ( $\mathrm{X} 1, \mathrm{X} 2$, dan $\mathrm{X} 3$ ) terhadap variabel dependent (Y). Literasi keuangan ibu rumah tangga tidak akan lepas dari tingkat pendapatan, tingkat pendidikan dan tingkat pekerjaan. Bisa disimpulkan bahwa pendapatan yang tinggi akan berpengaruh terhadap literasi keuangan, semakin tinggi pendidikan yang dicapai akan mempengaruhi literasi keuangan dan juga pekerjaan semakin luas ruang lingkup maka akan mempengaruhi literasi keuangan.

\section{DAFTAR PUSTAKA}

Ary Gantika, E. (2018). Analisis Faktor-Faktor Yang Mempengaruhi Tingkat Literasi Keuangan Pada Ibu Rumah Tangga di Kota Padang (Vol. 05).

Dikdasmen, D. (2017). Materi Pendukung Literasi Finansial. Jakarta: Kementerian Pendidikan Dan Kebudayaan Republik Indonesia. Retrieved from http://dikdasmen.kemdikbud.go.id

Dwiastanti, A., \& Hidayat, W. (2016). Literasi Keuangan Ibu Rumah Tangga Dalam Membentuk Perilaku Keuangan Keluarga. Prosiding SNA MK, 28 September 2016, Hlm. 1-12, 1-12..

Lubis, U. (2017). Ekonomi OJK : Literasi Keuangan Indonesia. pp. 1-9. Retrieved from https://www.rappler.com/indonesia/ekonomi/159498-ojk-literasi-keuanganindonesia-2016

Marpis Ade, Cholid Idham, J. R. (2017). Pengaruh Usia, Pendidikan, Dan Pendapatan Terhadap Tingkat Literasi Keuangan Pada Ibu Rumah Tangga (Studi Kasus Kelurahan 5 Ulu Darat Kecamatan Seberang Ulu 1 Kota Palembang). 1-6.

Mulyani, N. (2016). Departemen Pendidikan Dan Kebudayaan,. Palembang. 


\section{Buletin Ekonomi}

Purwidianti, Wida dan Mudjiyanti, R. (2013). Analisis Pengaruh Pengalaman Keuangan Dan Tingkat Pendapatan Terhadap Perilaku Keuangan Keluarga Di Kecamatan Purwokerto Timur. BENEFIT Jurnal Manajemen Dan Bisnis, 1(2), 141-148. 